\title{
An investigation into how EFL learners emotionally respond to teachers' oral corrective feedback
}

\section{Una investigación sobre cómo los aprendices del inglés como idioma extranjero responden a la retroalimentación oral de sus profesores}

\author{
Juan de Dios Martínez Agudo \\ University of Extremadura \\ jdmtinez@unex.es
}

Received 20-Aug-2012/Accepted: 26-Oct-2013

\begin{abstract}
This research study draws on research in SLA and language pedagogy and hopes to throw some light on the pedagogical effectiveness of the oral feedback process in L2 classrooms by focusing exclusively on the potential affective damage that teachers' oral corrective feedback can cause among learners in classroom settings. The paper describes a study in which we investigated how EFL learners actually perceive or rather emotionally respond to the oral feedback process. This paper aims to investigate to what extent the way teachers provide oral corrective feedback is somehow associated with learners' motivations and attitudes. For this purpose, a short questionnaire was designed and distributed among a sample of $208 \mathrm{EFL}$ secondary school learners. The article first reviews the literature on the controversial role of corrective feedback in L2 classrooms. Next, the findings are reported and discussed. This research paper suggests that EFL learners emotionally respond to teachers' oral corrective feedback in different ways. Additionally, it found evidence that anxiety can have a negative effect on the way learners benefit from the oral feedback process. Thus, the paper issues warnings about the potential affective damage oral corrective feedback can cause among learners in classroom situations.
\end{abstract}

Key words: oral corrective feedback, affective damage.

\section{Resumen}

Este estudio de investigación se basa en la investigación sobre adquisición de segundas lenguas y pedagogía lingüística y pretende arrojar algo de luz sobre la eficacia pedagógica del proceso de retroalimentación oral en las aulas de segunda lengua, centrándose exclusivamente en el potencial daño afectivo que la retroalimentación correctiva oral de los docentes puede provocar entre los alumnos en las aulas. El artículo describe un estudio en el que se investigó cómo los estudiantes de inglés como lengua extranjera perciben en realidad o, más bien, cómo responden emocionalmente al proceso de retroalimentación oral. Este trabajo tiene como objetivo investigar en qué medida el modo en que los docentes proporcionan retroalimentación correctiva oral se asocia de alguna manera con las motivaciones y actitudes de los alumnos. Para ello, un breve cuestionario se diseñó y distribuyó entre una muestra de 208 estudiantes de secundaria de inglés como lengua extranjera. El artículo primero revisa la literatura sobre el controvertido papel de la retroalimentación correctiva en las aulas de segunda lengua. Seguidamente se presentan y discuten los resultados. Esta investigación sugiere que los estudiantes de inglés como lengua extranjera responden emocionalmente a la retroalimentación correctiva oral proporcionada por los docentes de diferentes maneras. Además, se encontró evidencia de que la ansiedad puede tener un efecto negativo en la forma en que los estudiantes se beneficien del proceso de retroalimentación oral. Por consiguiente, este trabajo lanza una advertencia sobre el daño afectivo potencial que la retroalimentación correctiva oral puede causar entre los estudiantes en situaciones de aula.

Palabras claves: retroalimentación oral correctiva, daño afectivo. 
Résumé

Cette étude de recherche a pour base la recherche sur l'acquisition de secondes langues et la pédagogie linguistique et prétend jeter un peu de lumière sur l'efficacité du processus de rétroaction orale dans les classes de seconde langue, nous limitant exclusivement à étudier les conséquences affectives potentielles que la rétroaction corrective orale des enseignants peut entraîner chez les élèves dans les classes. L'article décrit une étude où l'on a observé comment les étudiants d'anglais langue étrangère perçoivent en réalité le processus de rétroaction orale ou plutôt comment ils y répondent émotionnellement. Ce travail a pour but de rechercher dans quelle mesure la façon dont les enseignants proposent la rétroaction corrective répercute d'une certaine manière sur les motivations et les attitudes des étudiants. C'est pour cela qu'on a élaboré un bref questionnaire que l'on a distribué à un échantillon de 208 étudiants de secondaire d'anglais langue étrangère. L'article fait d'abord le tour de la littérature sur le rôle de la rétroaction corrective dans les clases de seconde langue. Ensuite,on présente les résultats et on en discute.Cette recherche révèle que les étudiants d'anglais langue étrangère répondent émotionnellement de différentes manières à la rétroaction corrective orale réalisée par les enseignants. En plus, il s'est avéré évident que l'anxiété peut avoir un effet négatif sur la façon dont les étudiants tirent profit du processus de rétroaction orale. En conséquence, ce travail lance un cri d'appel sur les conséquences affectives potentielles que la rétroaction corrective orale peut créer chez les étudiants en situation de clase.

Mots clés: rétroaction orale corrective, conséquences affectives.

\section{Introduction}

Over the last few decades the role and effectiveness of corrective feedback in classroom settings has been extensively debated in both SLA research and language pedagogy, becoming a highly controversial issue, with arguments both for and against providing feedback (see, for example, Russell 2009; Ellis 2009a; Sheen 2010a; Ellis 2011). Most research studies advocate the effectiveness of corrective feedback in classroom settings (e.g. Lyster E Ranta, 1997; Lyster 1998; Havranek, 1999; Han 2002; Panova E Lyster 2002; Mackey, et al., 2003; Sheen, 2004; Ellis, 2006, 2007; Bitchener, 2008; Ellis, et al., 2008; Ellis, 2009a; Lyster \& Saito, 2010; Bitchener E Knoch 2010; Ellis 2010, 2011; Farrokhi $\mathcal{E}$ Sattarpour 2012; Lyster, et al., 2013; Rassaei 2013; Erlam, et al., 2013; Lee, 2013). In addition, several meta-analyses have recently concluded that corrective feedback -whether oral or written- plays a facilitative role in SLA (Russell \& Spada 2006; Mackey E Go 2007; Lyster \& Saito, 2010; Shaofeng 2010; Li, 2010). However, research literature has also revealed different positions or opinions against error treatment. In fact, several scholars have expressed doubts about its effectiveness, or rather, have believed that feedback on errors should be avoided because it can have potentially negative effects on learners' affect and, consequently, on L2 learning (Krashen 1982; Schwartz
1993; Truscott 1999). In this respect, these scholars claimed that error treatment was not only unnecessary, but also potentially harmful to SLA. According to Krashen (1982, p. 75), corrective feedback "has the immediate effect of putting the student on the defensive". Truscott $(1999,441)$ also believed that feedback on error does not actually work because corrective feedback may cause "embarrassment, anger, inhibition, and feelings of inferiority" among learners. In fact, Truscott $(1999,2007)$ viewed error treatment as a traumatic experience and not at all helpful for students because its negative and harmful effects may discourage and demotivate learners. In this sense, Truscott (1999) advocates total rejection of any type of corrective feedback in L2 classrooms. Accordingly, both scholars (Krashen and Truscott) argued that SLA depends solely on positive evidence and thus negative evidence is not necessary and might even be harmful for L2 learners' interlanguage development. In short, the theoretical debate on the effectiveness or ineffectiveness of feedback on errors still continues and generates much controversy among SLA researchers, even though some of the studies reviewed so far support the view that corrective feedback plays a facilitative role in L2 acquisition in improving grammatical accuracy (Chandler, 2003; Sheen 2007; Bitchener $\mathcal{E}$ Knoch 2010). 
Corrective feedback is a highly complex instructional and interactive phenomenon that manifests cognitive, social and psychological dimensions (Ellis, 2009a). Most researchers acknowledge the cognitive contribution corrective feedback can make due to its facilitative role in L2 learning, whereas others issue warnings about the potential affective damage oral corrective feedback can cause among L2 learners in classroom situations (Ellis 2009a; Ayedh \& Khaled, 2011). In this respect, Ellis (2009a) reminds us that corrective feedback does not function as 'punishment' but it may inhibit or discourage learning. Second language pedagogy has highlighted the importance of positive feedback or reinforcement in providing affective support to the learner by stimulating motivation to continue learning (Ellis 2009a). Positive feedback or reinforcement is obviously something that is very important to the students. In fact, learners need to constantly feel encouraged to keep on learning. In contrast, negative evidence provided through corrective feedback may, at times, seriously damage learners' feelings and attitudes (Martínez, 2008). Accordingly, the potential affective damage corrective feedback can cause among learners needs to be seriously taken into consideration. In short, learner individual characteristics and affective aspects may influence the effectiveness of corrective feedback. A growing body of qualitative case study research has highlighted the importance of these factors in explaining learners' responses to the teacher's feedback (see Hyland 2003; Hyland \& Hyland 2006).

Emotions and feelings towards the feedback process are mainly dependent upon how feedback is actually managed (Ayedh $\mathcal{E}$ Khaled, 2011). Can oral corrective feedback, if used frequently, upset and discourage EFL learners? Of course it can. The question is how and how much. The fact is that corrective feedback can only be used to a limited extent, after which it can become discouraging and destructive (Ayedh $\&$ Khaled, 2011), even though too little can be equally counterproductive. Corrective feedback, if used too frequently, can be negative in terms of motivation and attitude and, accordingly, should be avoided at all cost. In fact, overcorrection could undermine the student's self-confidence. According to Storch $(2010,43)$, "Providing feedback on a large number of errors may overwhelm the learners, not to mention be extremely time consuming for the teachers". In this sense, teachers should know when and how to correct errors and, above all, should consider learners' sensitiveness and personality. Despite the fact that most learners find corrective feedback highly helpful and, thus, need and wish to be corrected regularly in class (Schulz, 2001; Havranek, 2002; Zacharias 2007; Lyster et al. 2013), the fact is that many of them also find corrections embarrassing to varying degrees. What language teachers should actually avoid is to make learners feel embarrassed or frustrated when being orally corrected in class-fronted situations. Most importantly, the teacher should be positive and kind. Rather, corrective feedback should always be delivered carefully and in a very positive way and, above all, nicely, so that students do not feel embarrassed. In this sense, corrective feedback should be used cautiously and tactfully -and not in a direct or obtrusive way-, bearing in mind students' attitudes and personalities when being orally corrected in classfronted situations. As Ayedh \& Khaled (2011, p. 216) claimed, "Feedback should always be personal, and never directed at the person's personality". Although implicit as well as explicit types of feedback have been shown to be beneficial, and both lead to learning, the fact is that implicit corrective feedback seems more desirable as learners do not feel any `direct criticism or attack' from the correction provided and, accordingly, their emotions are not so seriously affected. Learners sometimes find the criticism associated with corrective feedback difficult to handle, which makes them resist or reject the feedback process (Ayedh $\varepsilon$ Khaled, 2011). The fact is that corrective feedback cannot be provided in such way that students immediately react by putting themselves on the defensive. Thus, corrective feedback must be highly flexible, adapted to the individual learner and to the social/situational 
context (Ellis, 2009a). Given that anxiety can have a negative effect on the way learners benefit from the feedback process, L2 teachers should be much more concerned with learners' feelings and emotions when being orally corrected in class-fronted situations. The fact is that teachers are mainly concerned about not overcorrecting their students for fear of inducing language anxiety (Lasagabaster $\&$ Sierra, 2005). That is, they frequently worry about hurting the learners' feelings and damaging their self-esteem. Generally, the usefulness of teachers' oral corrective feedback is perceived and accepted by most learners, even though Lyster et al. (2013, p. 1) made clear that research on corrective feedback preferences reveals "a tendency for learners to prefer receiving CF more than teachers feel they should provide it". Rather, Lyster, et al., (2013, p. 8) pointed out that "the extent to which learners want to be corrected is generally greater than teachers' wish to provide correction". This is likely due to teachers' fear of discouraging the learners. In fact, teachers believe that corrective feedback can induce language anxiety, affecting students' self-esteem and motivation in a negative manner (Dörnyei, 1994; Lasagabaster E Sierra, 2005; Jean E Simard, 2011). Accordingly, the oral corrective feedback provided by teachers may be sometimes seen as a potential anxiety-provoking situation. In this respect, Dörnyei (1994, p. 282) insists on the idea of error treatment without generating anxiety by suggesting that we "use motivating feedback by making our feedback informational rather than controlling; giving positive competence feedback, pointing out the value of accomplishment; and not overreacting to errors". Arnold \& Brown (1999) also view corrective feedback as one of the major causes for language learner anxiety. In short, corrective feedback must take account of learners' affective needs in the sense that teachers should be prepared to vary the way they correct in accordance with the cognitive and affective needs of the individual learner in the classroom context (Ellis 2009a). Even Ellis (2010) suggests that teachers should abandon corrective feedback if it is a source of anxiety to a learner.
This complex area of research in SLA has been widely discussed from both theoretical and pedagogical perspectives (Guenette, 2007; Ellis, 2009a). Particularly, different perspectives (interactionist/cognitive theories and sociocultural theory) help to illuminate corrective feedback and the role it plays in L2 acquisition (Ellis, 2009a). In this respect, Ellis (2007) argued that "a general weakness of current accounts of CF is that they have focussed narrowly on the cognitive aspects of correction and acquisition and that a fuller understanding requires a consideration of the social context of $\mathrm{CF}$ and the psychological characteristics of individual learners". A full understanding of corrective feedback thus requires a multiple perspectives approach (Ellis, 2010). In fact, there are still many unexplored variables influencing differential effectiveness of corrective feedback (Lyster E Saito, 2010; Li, 2010; Lyster et al., 2013). Current research has moved from addressing whether corrective feedback actually works for language acquisition to examining what type of corrective feedback strategy works best in classroom settings (Ellis, 2009a). In this respect, Farrokhi \& Sattarpour $(2012,50)$ claim that "It is not just a question of whether CF is effective but also which type is effective". The fact is that it is still unclear which feedback strategy is more effective in classroom settings, that is, the findings are not yet conclusive (Ellis, 2010; Farrokhi \& Sattarpour, 2012). There is still debate over what types of corrective feedback are more effective (Russell \& Spada, 2006; Loewen $E$ Erlman, 2006; Loewen \& Nabei, 2007; Mackey \& Goo, 2007; Bitchener $\mathcal{E}$ Knoch, 2009) and, therefore, it is not easy to decide which type of feedback is best for all learners in all contexts. Although there does not actually exist any 'ideal corrective feedback recipe', the fact is that how teachers provide corrective feedback makes the difference. In this respect, considerable disagreement seems to exist over how best to handle corrective feedback and, accordingly, it is not still possible to specify general guidelines for corrective feedback that are appropriate for all instructional contexts (Ellis, 
2011). While feedback on error can be provided in a wide variety of ways, the fact is that learners also perceive and respond to corrective feedback in different ways (Lyster, et al. 1999). In this sense, Ellis (2009a) makes clear that what is best for one learner in one context will not necessarily be best for the same learner (or another learner) in a different context. Thus, Ellis (2009a) and Lyster \& Saito (2010) remind us that teachers need to adapt and adjust flexibly a wide variety of corrective feedback techniques to the particular learner's cognitive and affective needs. As is evident, this does not necessarily mean that they can correct all students in the same way. In fact, feedback on errors should be individualised, even though this evidently involves an enormous challenge for L2 teachers. What SLA research reveals is that corrective feedback strategy should be non-intrusive and unembarrasing to learners. Certainly, the effects of corrective feedback strategies have received a great deal of attention in SLA research (Lyster and Ranta, 1997; Iwashita 2003; Lyster 2004; Loewen 2004; Sheen 2004; Truscott 2004, 2007; Bitchener et al. 2005; Ellis E Sheen 2006; Ellis et al. 2008; Ellis 2009a, 2009b; Farrokhi $\mathcal{E}$ Sattarpour, 2012). Bearing in mind the considerable effort and time devoted to corrective feedback, the fact is that we know so little about it. Differences in opinions are evident in responses to the key issues facing teachers and teacher educators, such as whether corrective feedback contributes to L2 acquisition, which errors to correct, who should do the correcting (the teacher or the learner him/herself), which type of corrective feedback is the most effective, and what is the best timing for corrective feedback -immediate or delayed- (Ellis, 2009a). In fact, there does not exist a unifying view of corrective feedback in SLA research due mainly to theoretical disputations and different research findings. Although most SLA research studies suggest evidence of the efficacy of corrective feedback (Han 2002; Chandler, 2003; Lyster 2004; Bitchener et al. 2005; Sheen, 2007; Bitchener E Knoch, 2009), Hyland and Hyland, (2006, p. 84) claimed that "it is difficult to draw any clear conclusions and generalizations from the literature as a result of varied populations, treatments and research designs". Particularly, limitations in the design (see Guenette, 2007; Bitchener 2008 for discussion of these issues) and differences in their contexts and in the proficiency level of their participants make it difficult to assess the value of the claims made (Farrokhi $\mathcal{E}$ Sattarpour 2012). In short, further research on the emotional damage or impact associated with oral corrective feedback in L2 classrooms is actually needed.

\section{Research questions}

Despite the potential facilitative role of corrective feedback in SLA, the main emphasis of this paper lies on the emotional aspects associated with oral corrective feedback, or rather on how L2 learners emotionally respond to the oral feedback process in L2 classrooms. Likewise, this research study sets out to investigate to what extent the way teachers provide oral corrective feedback is associated with learners' motivations and attitudes towards L2 learning. Accordingly, this article sets out to fill this important gap in the research literature which has so far been unexplored. As is evident, this research has important implications for language learning and teaching. In short, the present study aims to shed some light on the answer to the following research questions:

- How do learners emotionally respond to the oral feedback process?

- To what extent does teachers' oral corrective feedback influence EFL learners' motivations and attitudes towards L2 learning?

\section{Method}

\section{Participants}

The present research study has been carried out in secondary schools located in Extremadura, an autonomous region of western Spain, on the border with Portugal. We collected data from four secondary schools which were randomly selected, particularly two classes from each school. A total of 217 Spanish secondary school students participated 
in the investigation voluntarily. After receiving 217 questionnaires, the researcher discarded 9 invalid questionnaires which were either incomplete or failed to follow the instructions of the questionnaire. Accordingly, the valid response rate was $95.85 \%$ and a total of 208 questionnaires were identified as valid data for statistical analysis in the present study. A sample of 208 Spanish secondary school learners was eventually employed, of these 95 (45.67\%) were males and 113 (54.32\%) were females. Of the 208 students 97 (46.63\%) were in the first year of Bachillerato and 111 (53.36\%) were in the second year. Their average age was 17 , ranging from sixteen to nineteen. Additionally, the participants in the survey had studied English for an average of 14 years. The average classroom level was upper intermediate.

\section{Instrument and data collection procedure}

Data collection took place during the scheduled class time in March 2013. A short 10item questionnaire was specially designed for this purpose to gather information on how EFL learners emotionally respond to the oral feedback process in classroom situations. A thorough content analysis and pilot test were performed to ensure the reliability and validity of the questionnaire. Before designing the final questionnaire, a critical review of the questionnaire was also conducted by other subject matter experts to obtain suggestions for improvement. Particularly, the wording of statements is essential in ensuring we obtain the information required to answer our research questions. In this respect, ambiguous wording must be avoided so as to avoid possible erroneous responses. The questionnaire was administered by the researcher himself, who explained the purpose and potential usefulness of the survey and also made clear to the participants that their responses would be used for research purposes only. After reminding our group of informants of the importance of giving honest answers, they were assured of the confidentiality of the data. The questionnaires were completed anonymously in class and handed back on completion.

\section{Analysis and discussion of results}

Quantitative data from the questionnaire were only utilised for descriptive statistics to answer the aforementioned research questions. Table 1 displays the results of descriptive statistics.

Table 1. Descriptive statistics of learners' responses.

\begin{tabular}{|c|c|c|c|c|c|}
\hline STRONGLY DISAGREE & DISAGREE & $\begin{array}{l}\text { NEITHER AGREE } \\
\text { NOR DISAGREE }\end{array}$ & AGREE & STRONGLY AGREE & TOTAL \\
\hline \multicolumn{6}{|c|}{ Statement 1. I feel I have learnt a lot from being orally corrected. } \\
\hline $4.95 \%$ & $6.93 \%$ & $21.78 \%$ & $48.51 \%$ & $17.82 \%$ & $100.00 \%$ \\
\hline \multicolumn{6}{|c|}{ Statement 2. I think that the oral feedback provided is necessary and helpful. } \\
\hline $0.99 \%$ & $4.95 \%$ & $8.91 \%$ & $51.49 \%$ & $33.66 \%$ & $100.00 \%$ \\
\hline \multicolumn{6}{|c|}{ Statement 3. I resent it when I make oral mistakes. } \\
\hline $3.96 \%$ & $6.93 \%$ & $27.72 \%$ & $40.59 \%$ & $20.79 \%$ & $100.00 \%$ \\
\hline \multicolumn{6}{|c|}{ Statement 4. I worry about making oral mistakes in language class. } \\
\hline $3.96 \%$ & $12.87 \%$ & $18.81 \%$ & $42.57 \%$ & $21.78 \%$ & $100.00 \%$ \\
\hline \multicolumn{6}{|c|}{ Statement 5. I hate making oral mistakes because they make me doubt myself. } \\
\hline $10.89 \%$ & $15.84 \%$ & $25.74 \%$ & $26.73 \%$ & $20.79 \%$ & $100.00 \%$ \\
\hline \multicolumn{6}{|c|}{ Statement 6 . I resent being orally corrected by the teacher in the classroom. } \\
\hline $34.65 \%$ & $45.54 \%$ & $15.84 \%$ & $2.97 \%$ & $0.99 \%$ & $100.00 \%$ \\
\hline \multicolumn{6}{|c|}{ Statement 7. I get upset when I don't understand what the teacher is correcting. } \\
\hline $6.93 \%$ & $15.84 \%$ & $17.82 \%$ & $38.61 \%$ & $20.79 \%$ & $100.00 \%$ \\
\hline
\end{tabular}




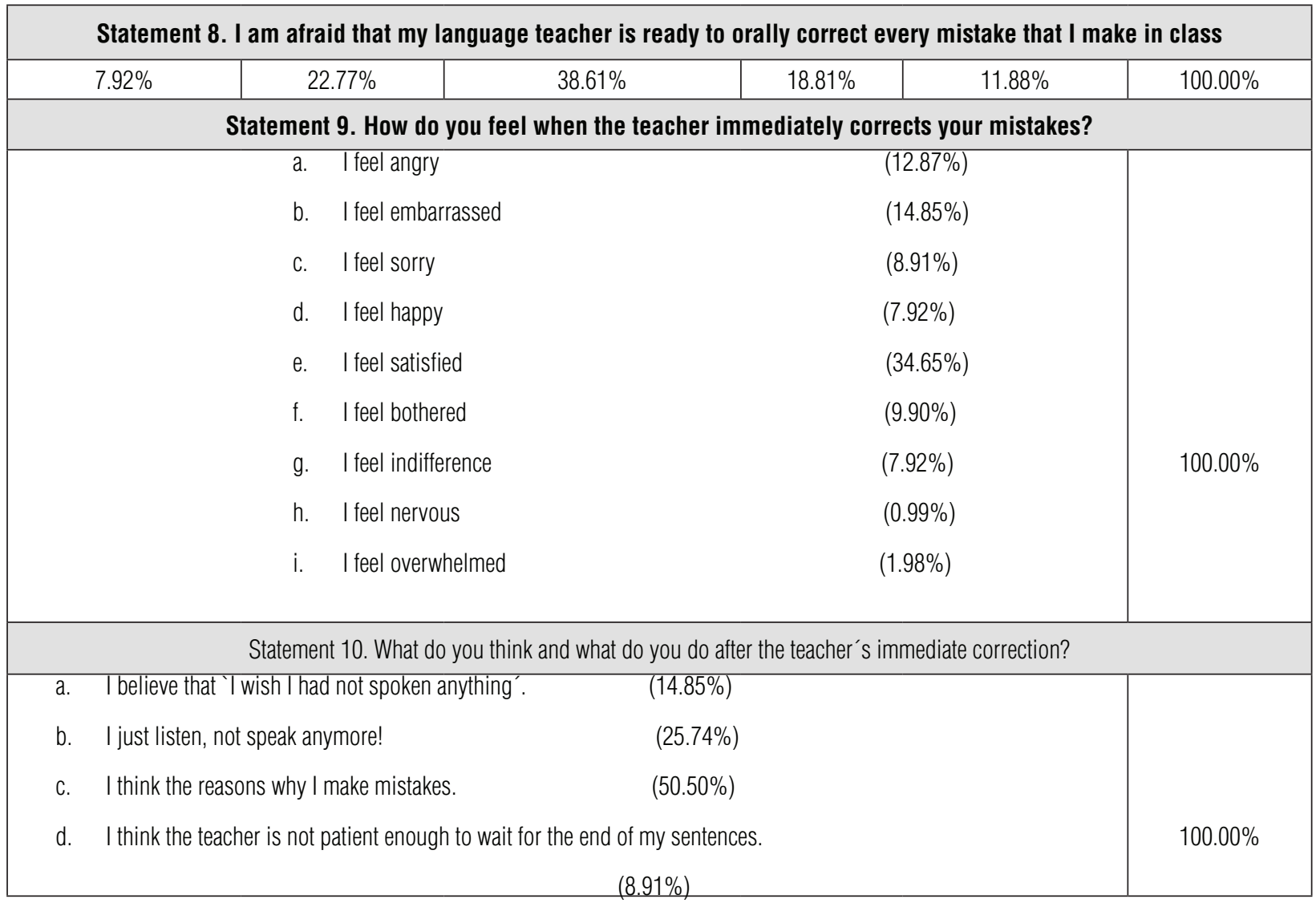

Note: Scores are based on a 1 to 5 scale in which 1 represents "strongly disagree" and 5 represents "strongly agree".

Table 1. reports the results obtained from learners' responses with percentages of students selecting each alternative. After the data-gathering process, the next step was to synthesize and analyze the results. As displayed in Figure 1, several statements generated very high levels of agreement ('strongly agree' and 'agree').

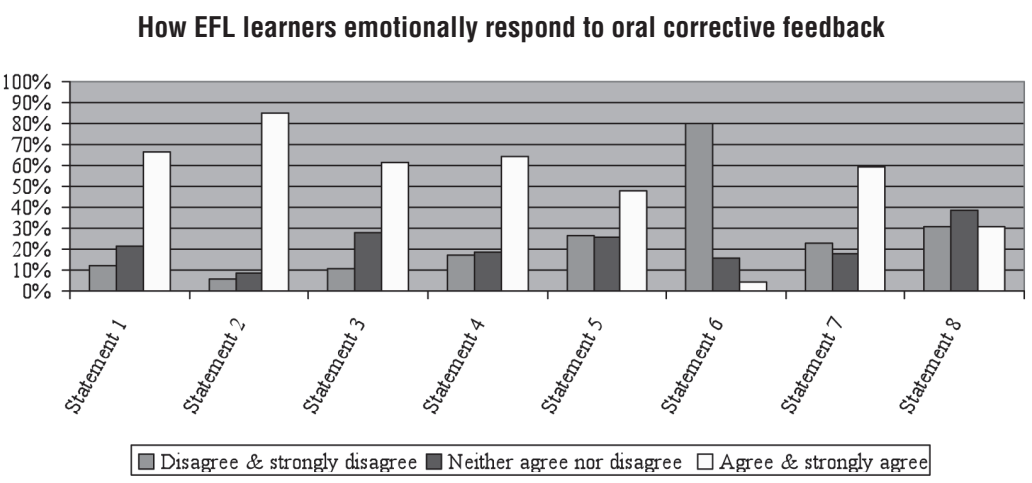

Figure 1. Descriptive Statistics of learner's responses 
As displayed in Table 1 and illustrated in Figure 1, the statement which obtained the highest percentage is statement 2 which concerns the effectiveness of the oral feedback process. In fact, most respondents (85.15\%) acknowledge the need and usefulness of the oral feedback provided by teachers in classroom situations. Additionally, two thirds of the participants (66.33\%) also recognize that they have learned a lot from the oral feedback provided (statement 1). It is somehow suggested that oral corrective feedback is essential and helpful in developing interlanguage competence.

With respect to the emotional responses derived from the oral feedback process, which is the main focus of this study, several statements provide us with useful information on to what extent teachers' oral corrective feedback emotionally influences EFL learners and how these respond or react to the oral feedback process. In this respect, we can see how nearly two-thirds of the respondents resent and worry about making oral mistakes in classroom situations
$-61.38 \%$ and $64.35 \%$, respectively- (statements $3 \varepsilon$ 4). Additionally, nearly half of the subjects surveyed (47.52\%) hate making oral mistakes because these make them doubt themselves and their learning possibilities (statement 5). However, while most respondents $(80.19 \%)$ do not resent having to be orally corrected by their teachers in the classroom (statement 6), nearly 60\% (specifically, 59.4\%) of the participants recognise feeling upset when they do not understand what their teachers are correcting (statement 7). Additionally, only one third of the subjects $(30.69 \%)$ are actually afraid that their teachers are ready to orally correct every mistake they make in class (statement 8).

In response to the question of how EFL learners actually feel when their teachers immediately correct their mistakes, several choices were considered. As illustrated in Figure 2, we can see that 'feeling satisfied' becomes the top choice (34.65\%), followed by 'feeling embarrassed' (14.85\%) and then 'feeling angry” (12.87\%).

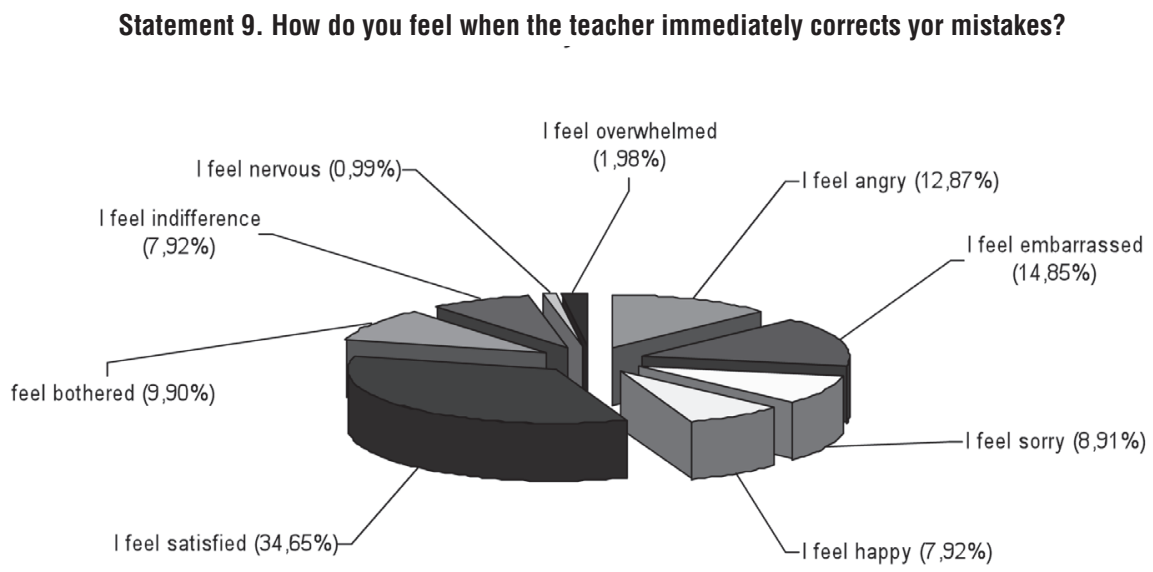

Figure 2. Graphical Illustration of Percentages of responses concerning statement 9

In response to the question of what EFL learners actually think and what they do after the teachers' immediate correction, several options were also assessed. As illustrated in Figure 3, we can see that about half of the participants think about the reasons why they make mistakes (namely, 50,50\%), becoming thus the top choice, followed by their refusal to continue speaking for the rest of the lesson $(25,74 \%)$. 


\section{Statement 10. What do you think and what do you do after the teacher's immediate correction?}

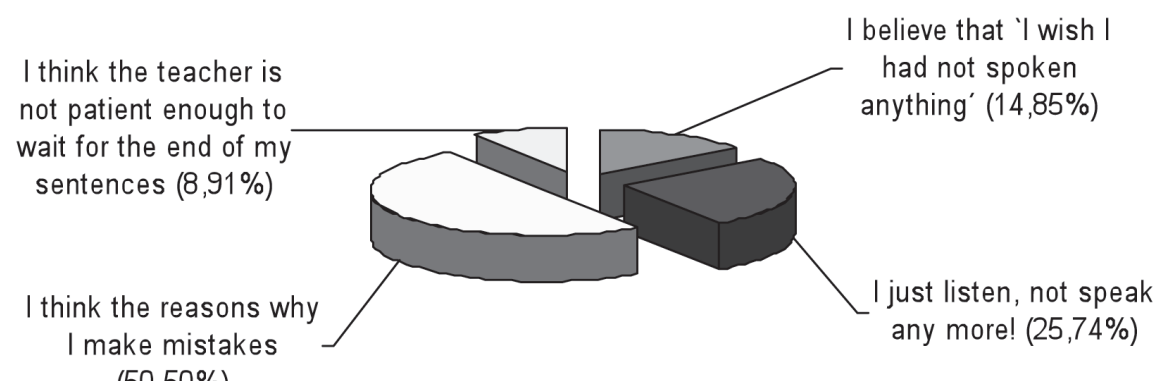

$(50,50 \%)$

Figure 3. Graphical representation of percentages of responses concerning statement 10

Although the data shown in Table 1 reveal different percentages of responses, the data obtained are consistent enough to draw several conclusions. However, several limitations in the research design make it difficult to make overall generalizations about the potential implications of this research study. Namely, the insufficient number of participants ( $\mathrm{n}$ $=208$ ) could be seen as the greatest limitation of the present research study. Thus, caution should be exercised in generalizing the current findings beyond this student population, until further research investigates in more detail. Because of the very limited size of the sample, research findings call for replication on larger populations and in different teaching contexts. For future studies, a greater number of participants and the inclusion of more open-ended questions in the research instrument could be also considered. Interviews as qualitative research method would be also helpful for gathering additional data. As such, conclusions made in this study should be taken as indicative of the need for further research on the emotional aspects associated with oral corrective feedback in L2 classrooms.

\section{Conclusions and suggestions for future research}

The main goal of this research article was to analyze how learners emotionally respond to the oral feedback process in L2 classrooms and to what extent teachers' oral corrective feedback may influence their motivations and attitudes towards L2 learning. Particularly, this research paper suggests that EFL learners emotionally respond to teachers' oral corrective feedback in different ways. Although further research would be needed as confirmation, this study revealed that most learners find teachers' oral corrective feedback highly helpful which somehow suggests that they expect and wish to be corrected regularly in classroom settings. Interestingly, however, while a high percentage of respondents resent and worry about making oral mistakes in the classroom context, most of them do not resent being orally corrected in the classroom. What actually makes them feel upset is when they do not actually understand what their teachers are correcting. Likewise, this study found evidence that some students also find 
oral corrective feedback inhibiting and embarrassing to varying degrees, even though a significantly higher percentage of respondents recognize that they feel satisfied with the oral feedback provided by teachers. The resulting data somehow suggests that the way teachers provide oral corrective feedback may influence to a certain extent learners' feelings and attitudes, particularly when these are unable to fully understand the teacher feedback, which is often ambiguous and inconsistent (Ellis 2005). Accordingly, the findings of the current study are consistent with reports from previous studies (Martínez 2008; Ellis 2009a; Storch 2010; Ayedh E Khaled 2011) that have found that corrective feedback may damage the learners' feelings and discourage the process of learning if used very frequently. In short, the paper issues warnings about the potential affective damage oral corrective feedback can at times cause among learners in classroom situations. In this sense, we express strong reservations concerning the emotional impact that corrective feedback has on SLA.

Despite the numerous research studies on corrective feedback effectiveness conducted over the last decades, many questions still remain unanswered. Little is understood about how corrective feedback assists L2 development (Rassaei 2013). In addition to the debate about whether or not corrective feedback can be effective in classroom settings, future studies will be needed to investigate the complex of variables that affect the pedagogical effectiveness of corrective feedback in L2 classrooms (Lyster $\mathcal{E}$ Saito 2010). Specifically, there is a need to investigate the effectiveness or rather the possible effects of each type of corrective feedback separately. Likewise, there is still a need for further longitudinal studies to increase our understanding of the nature of corrective feedback and its impact or differential effects on L2 learning (Iwashita 2003; Liang 2008; Bitchener $\varepsilon$ Knoch 2010; Sheen 2010b; Farrokhi E Sattarpour 2012). Additionally, more research into student and teacher beliefs and attitudes towards oral corrective feedback is also needed (Basturkmen et al. 2004;
Lasagabaster E Sierra 2005; Mackey et al. 2007; Montgomery \& Baker 2007; Zacharias 2007; Rassaei 2013; Lee 2013). In this respect, we recommend further studies to replicate and extend the current research framework. In order to better understand the emotional impact associated with oral corrective feedback in L2 classrooms, future studies need to adopt a more qualitative and ecologically valid research design (Storch 2010).

\section{Acknowledgements}

I would like to thank all the participants in the study for their kind collaboration.

\section{References}

Arnold, J., \& Brown, H. D. (1999). A map of the terrain. In J. Arnold (Ed.), Affect in Language Learning (pp. 1-24). Cambridge: Cambridge University Press.

Ayedh, A., \& Khaled, E. (2011). EFL teachers' feedback to oral errors in EFL classroom: Teachers' perspectives. Arab World English Journal, 2, (1), 214-232.

Basturkmen, H., Loewen, S., \& Ellis, R. (2004). Teachers' stated belief about incidental focus on form and their classroom practices. Applied Linguistics, 25, 243-272.

Bitchener, J. (2008). Evidence in support of written corrective feedback. Journal of Second Language Writing, 17, 102-118.

Bitchener, J., \& Knoch, U. (2009). The relative effectiveness of different types of direct written corrective feedback. System, (37), 322-329.

Bitchener, J., \& Knoch, U. (2010). The contribution of written corrective feedback to language development: A ten month investigation. Applied Linguistics, 31, 193-214.

Bitchener, J., Young, S., \& Cameron, D. (2005). The effect of different types of corrective feedback on ESL student writing". Journal of Second Language Writing, 14, 191-205.

Chandler, J. (2003). The efficacy of various kinds of error feedback for improvement in the accuracy and fluency of L2 student writing. Journal of Second Language Writing, 12, 267-296.

Dörnyei, Z. (1994). Motivation and motivating in the foreign language classroom. The Modern Language Journal, 78, (3), 273-284. 
Ellis, R. (2005). Instructed Second Language Acquisition: A Literature Review. Wellington, New Zealand: New Zealand Ministry of Education. Available online at http://www.educationcounts.govt.nz/_data/assets/ pdf_file/0008/6983/instructed-second-language.pdf

Ellis, R. (2006). Researching the effects of form-focused instruction on L2 acquisition. AILA, 19, 18-41.

Ellis, R. (2007). Corrective feedback in theory, research and practice. In: The $5^{\text {th }}$ International Conference on ELT in China \& the $1^{\text {st }}$ Congress of Chinese Applied Linguistics, May 17-20, Beijing Foreign Language Studies University, Beijing, China. Available online at http://www.celea.org.cn/2007/keynote/ppt/Ellis.pdf

Ellis, R. (2009a). Corrective feedback and teacher development. L2 Journal, 1, 1, 3-18.

Ellis, R. (2009b). A typology of written corrective feedback types. English Language Teaching Journal, 63, 97-107.

Ellis, R. (2010). Cognitive, social and psychological dimensions of corrective feedback. In R. Batstone (Ed.), Sociocognitive Perspectives on Language Use and Language Learning (pp. 151-165). Oxford: Oxford University Press.

Ellis, R. (2011). A principled approach to incorporating second language acquisition research into a teacher education programme. Reflections on English Language Teaching, 9 (1), 1-17.

Ellis, R., \& Sheen, Y. (2006). Re-examining the role of recasts in SLA. Studies in Second Language Acquisition, 28, 575-600.

Ellis, R., Sheen, Y., Murakami, M., \& Takashima, H. (2008). The effects of focused and unfocused written corrective feedback in an English as a foreign language context”. System, 36, 353-371.

Erlam, R., Ellis, R., \& Batstone, R. (2013). Oral corrective feedback on L2 writing: Two approaches compared. System, 41 (2), 257-268.

Evans, N.W., Hartshorn, K.J., McCollum, R.M., \& Wolfersberger, M. (2010). Contextualizing corrective feedback in second language writing pedagogy. Language Teaching Research, 14, 445-463.

Farrokhi, F., \& Sattarpour, S. (2012). The effects of direct written corrective feedback on improvement of grammatical accuracy on high-proficient L2 learners". World Journal of Education, 2 (2), 49-57.

Guenette, D. (2007). Is feedback pedagogically correct? Research design issues in studies of feedback on writing. Journal of Second Language Writing, 16, 40-53.

Han, Z. H. (2002). Rethinking of corrective feedback in communicative language teaching. RELC Journal, 33, 1-33.

Havranek, G. (1999). The effectiveness of corrective feedback: Preliminary results of an empirical study. Acquisition et Interaction en langue étrangère: Proceedings of the Eighth EUROSLA Conference, 2, 189-206.

Havranek, G. (2002). When is corrective feedback most likely to succeed?. International Journal of Educational Research, 37, 255-270.

Hyland, F. (2003). Focusing on form: Student engagement with teacher feedback. System, 31 (2), 217-230.

Hyland, K., \& Hyland, F. (2006). Feedback in Second Language Writing: Contexts and Issues. Cambridge: Cambridge University Press.

Iwashita, N. (2003). Negative feedback and positive evidence in task-based interaction: Differential effects on L2 development. Studies in Second Language Acquisition, 25 (1), 1-36.

Jean, G., \& Simard, D. (2011). Grammar learning in English and French L2: Students' and teachers' beliefs and perceptions. Foreign Language Annals, 44 (4), 465-492.

Krashen, S. (1982). Principles and Practice in Second Language Acquisition. Oxford: Pergamon Press.

Lasagabaster, D., \& Sierra, J.M. (2005). Error correction: Students' versus teachers' perceptions. Language Awareness, 14 (2-3), 112-127.

Lee, E. J. (2013). Corrective feedback preferences and learner repair among advanced ESL students. System, 41 (2), 217-230.

Li, Sh. (2010). The effectiveness of corrective feedback in SLA: A Meta-Analysis. Language Learning, 60, 2, 309-365.

Liang, Y. (2008). The effects of error feedback in second language writing. Second Language Acquisition and Teaching, 15, 65-79.

Loewen, S. (2004). Uptake in incidental focus on form in meaning-focused ESL lessons. Language Learning, $54,153-188$.

Loewen, S., \& Erlman, R. (2006). Corrective feedback in the chatroom: An experimental study. Computer Assisted Language Learning, 19 (1), 1-14.

Loewen, S., \& Nabei, T. (2007). Measuring the effects of oral corrective feedback on L2 knowledge. In A. 
Mackey (Ed.), Conversational Interaction in Second Language Acquisition: A Collection of Empirical Studies (pp. 361-377). Oxford: Oxford University Press.

Lyster, R. (1998). Negotiation of form, recasts, and explicit correction in relation to error types and learner repair in immersion classrooms. Language Learning, $48,183-218$.

Lyster, R. (2004). Differential effects of prompts and recasts in form-focused instruction. Studies in Second Language Acquisition, 26, 399-432.

Lyster, R., \& Ranta, L. (1997). Corrective feedback and learner uptake: Negotiation of form in communicative classrooms. Studies in Second Language Acquisition, 20, 37-66.

Lyster, R., \& Saito, K. (2010). Oral feedback in SLA classroom research: A meta-analysis. Studies in Second Language Acquisition, 32 (2), 265-302.

Lyster, R., Lightbown, P. M., \& Spada, N. (1999). A response to Truscott's 'What's wrong with oral grammar correction'. Canadian Modern Language Review, 55 (4), 457-467.

Lyster, R., Saito, K. \&, Sato, M. (2013). Oral corrective feedback in second language classrooms. Language Teaching, 46 (1), 1-40.

Mackey, A., \& Goo, J. (2007). Interaction research in SLA: A meta-analysis and research synthesis. In A. Mackey (Ed.), Conversational Interaction in Second Language Acquisition: A Collection of Empirical Studies (pp. 407-452). Oxford: Oxford University Press.

Mackey, A., Al-Khalil, M., Atanassova, G., Hama, M., Logan-Terry, A., Nakatsukasa, K. (2007). Teachers' intentions and learners' perceptions about corrective feedback on the L2 classroom. Innovation in Language Learning and Teaching, 1 (1), 129-152.

Mackey, A., Oliver, R., \& Leeman, J. (2003). Interactional input and the incorporation of feedback: An exploration of NS-NNS and NNS-NNS adult and child dyads. Language Learning, 53 (35)-66.

Martínez, J. D. (2008). Linguistic risk-taking and corrective feedback. In J. D. Martínez (Ed.), Oral Communication in the EFL Classroom (pp. 165-193). Sevilla: Ediciones Alfar.

Montgomery, J., \& Baker, W. (2007). Teacher-written feedback: Student perceptions, teacher self-assessment, and actual teacher performance. Journal of Second Language Writing, 16, 82-99.

Panova, I., \& Lyster, R. (2002). Patterns of corrective feedback and uptake in an Adult ESL classroom. TESOL Quarterly, 36, (4), 573-595.
Rassaei, E. (2013). Corrective feedback, learners' perceptions, and second language development. System, 41 (2), 472-483.

Russell, J., \& Spada, N. (2006). The effectiveness of corrective feedback for the acquisition of $L 2$ grammar. A metaanalysis of the research. In J. M. Norris \& L. Ortega (Eds.) Synthesizing Research on Language Learning and Teaching (pp. 133-164). Philadelphia: John Benjamins.

Russell, V. (2009). Corrective feedback, over a decade of research since Lyster and Ranta (1997): Where do we stand today? Electronic Journal of Foreign Language Teaching, 6 (1), 21-31.

Schulz, R. A. (2001). Cultural differences in student and teacher perceptions concerning the role of grammar instruction and corrective feedback: USA-Columbia. Modern Language Journal, 85, 244-258.

Schwartz, B. (1993). On explicit and negative data effecting and affecting competence and linguistic behavior. Studies in Second Language Acquisition, 15, 147-163.

Shaofeng, L. (2010). The effectiveness of corrective feedback in SLA: A meta-analysis. Language Learning, 62, 2, 309-365.

Sheen, Y. (2004). Corrective feedback and learner uptake in communicative classrooms across instructional settings. Language Teaching Research, 8 (3), 263-300.

Sheen, Y. (2006). Exploring the relationship between characteristics of recasts and learner uptake. Language Teaching Research, 10, 361-392.

Sheen, Y. (2007). The effect of focused written corrective feedback and language aptitude on ESL learners' acquisition of articles. TESOL Quarterly, 41, 255283.

Sheen, Y. (2010a). The role of oral and written corrective feedback in SLA. Studies in Second Language Acquisition, 32, 169-179.

Sheen, Y. (2010b). Differential effects of oral and written corrective feedback in the ESL classroom". Studies in Second Language Acquisition, 32, 203-234.

Sheen, Y., Wright, D., \& Moldawa, A. (2009). Differential effects of focused and unfocused written correction on the accurate use of grammatical forms by adult ESL learners. System, 37, 556-569.

Storch, N. (2010). Critical feedback on written corrective feedback research. International Journal of English Studies, 10 (2), 29-46. 
Truscott, J. (1999). What's wrong with oral grammar correction. The Canadian Modern Language Review, 55 (4), 437-455.

Truscott, J. (2004). Evidence and conjecture on the effects of correction: A response to Chandler. Journal of Second Language Writing, 13, 337-343.

Truscott, J. (2007). The effect of error correction on lear- ners' ability to write accurately. Journal of Second Language Writing, 16, 255-272.

Yoshida, R. (2008). Teachers' choice and learners' preference of corrective feedback types. Language awareness, 17, 1, 78-93.

Zacharias, T. (2007). Teacher and student attitudes towards feedback. RELC Journal, 38, 38-52.

\section{Appendix}

Read the following statements and rate them from 1 to 5,1 standing for 'I strongly disagree' and 5 standing for 'I strongly agree' with 3 being the neutral rating.

$$
\begin{array}{lcc}
1=\mid \text { strongly disagree } & 3=\mid \text { neither agree } & 4=\mid \text { agree } \\
2 \text { = I disagree } & \text { nor disagree } & 5=\mid \text { strongly agree }
\end{array}
$$

* If you are not sure what the question means, just leave it blank.

(_) 1. I feel I have learnt a lot from being orally corrected.

(_) 2. I think that the oral feedback provided is necessary and helpful.

(_) 3. I resent it when I make oral mistakes.

(_) 4. I worry about making oral mistakes in language class.

(_) 5 . I hate making oral mistakes because they make me doubt myself.

(_) 6. I resent being orally corrected by the teacher in the classroom.

(_) 7. I get upset when I don't understand what the teacher is correcting.

(__) 8. I am afraid that my language teacher is ready to orally correct every mistake that I make in class

9. How do you feel when the teacher immediately corrects your mistakes?

(_) a. I feel angry

(_) b. I feel embarrassed

(_) c. I feel sorry

(_) d. I feel happy

(_) e. I feel satisfied

(__ f. I feel bothered

(__ g. I feel indifference

(_) h. I feel nervous 
(_) i. I feel overwhelmed

10. What do you think and what do you do after the teacher's immediate correction?

(_) a. I believe that 'I wish I had not spoken anything'.

(_) b. I just listen, not speak anymore!

(_) c. I think the reasons why I make mistakes.

(_) d. I think the teacher is not patient enough to wait for the end of my sentences.

\section{THE AUTHOR}

JUAN DE DIOS MARTíNEZ AGUDO is an Associate Professor of EFL Teacher Education at the Faculty of Education of the Universidad de Extremadura (Spain) and head of the research group in English Language Teaching and Learning. His current research interests include second language acquisition and English language teaching and L2 teacher education. He has published several books and research articles on these areas in national and international publications. His most recent edited books are Oral Communication in the EFL Classroom (2008), Errors in the Second Language Classroom: Corrective Feedback (2010) and Teaching and Learning English through Bilingual Education (2012). 